\title{
CAUSALITY ANALYSIS BETWEEN STOCK MARKET INDICES
}

\author{
Pawel Sekula \\ University of Lodz, Lodz, Poland \\ e-mail: pawel.sekula@uni.lodz.pl \\ ORCID: 0000-0002-1959-8378 \\ (C) 2019 Paweł Sekuła \\ This is an open access article distributed under the Creative Commons Attribution-NonCommercial- \\ -NoDerivs license (http://creativecommons.org/licenses/by-nc-nd/3.0/)
}

DOI: 10.15611/fins.2019.1.05

JEL Classification: C32, G01, G15

\begin{abstract}
Summary: The paper examines relationships between selected stock market indices in Western Europe, Central Europe, and the United States. The study focuses on two periods, from January 1998 to August 2006 and from September 2006 to December 2016. The first one includes stock quotes from before the financial crisis while the second one covers the crisis and changes in the economic situation in post-crisis years. Relationships between stock market indices in developed economies were more frequent and durable than in Central Europe, although they were subject to changes. In our investigation into Granger causality relationships we observed changes in these relationships and in their direction for stock markets in Central Europe, while bidirectional relationships between indices in developed economies remained stable over time. Changes in relationships between indices, in particular long-term interdependences, may result from the impact of the 2008 financial crisis. The increased number of causality relationships for the markets in Central Europe may testify to the advancing integration of the EU common market.
\end{abstract}

Keywords: stock market, cointegration, Granger causality, financial crisis.

\section{Introduction}

The internationalisation of financial market transactions has been observed for several years. The process undergoes only some evolutionary changes and periodically speeds up or slows down [Lothian 2002]. In recent years, the 2008 crisis shook the foundations of financial markets leaving clear signs on the monetary and economic policies of many countries [Cukierman 2013]. The deep and rapid macroeconomic downturn triggered the use of a number of countercyclical policy instruments that could differentiate the performance of prices of assets across countries [Laeven, Tong 2012]. The last two decades also witnessed the significant growth and development of emerging markets, especially in Central Europe, where 
it was triggered by political and systemic transformations. The growth of the emerging markets was reflected in increasing internationalization [Tintin 2013]. For instance, the biggest stock market in Central Europe, the Warsaw Stock Exchange, reported an increase in the share of foreign investors' stock from 32\% in 1996 to $53 \%$ in 2016 [GPW 2017]. This gave the impulse to examine the relationships between stock market indices in Western Europe, Central Europe, and the United States. Our goal was to investigate the interrelationships among selected stock indices and the impact of the 2008 financial crisis upon the relationships among the stock markets covered by the study.

\section{Literature review}

Empirical studies into the relationships between indices in financial markets reveal some dependences and changes in this regard. Hilliard used daily closing prices and showed the relationships between the main indices in global markets [Hilliard 1979]. Malliaris and Urrita carried out causality tests for the main stock markets before, during and after the stock market crash of October 1987. They examined relationships among the markets only during the time of crash of 1987 [Malliaris, Urrita 1992]. Smith, Brocato and Rogers, based on weekly rates of return, demonstrated causality relationships among stock markets in the United States, Japan, Germany, and the UK [Smith et al. 1993]. Kwan, Sim and Cotsomitis analysed causality relationships of monthly rates of return for nine stock indices worldwide. They stressed that the results challenge the efficient market hypothesis; over the period covered by the study they found evidence of eight significant cointegrations and 30 significant Granger causality relationships [Kwan et al. 1995]. Surveys into interrelationships between stock markets were also conducted based on stock market indices from pre and post-globalisation periods. Masih, Masih examined relationships between the major global stock markets. They demonstrated that the United States market played a significant role in explaining changes in the economic situation in other markets in each of these periods. In the Japanese market a clear shift took place, as a result of which it became clearly independent of the global market performance. On the other extreme of the spectrum, the UK market in the post-globalisation period clearly grew increasingly dependent on changes in economic situation in international markets [Masih, Masih 2002]. Causality relationships between the markets, and especially the powerful impact of the US and UK markets, were also documented in earlier studies by the same authors [Masih, Masih 2001]. Syriopoulos investigated the short and long-term relationships between stock markets in Central Europe, Germany and in the United States. Analysis showed cointegration relationships; markets in Central Europe were more strongly related to markets in developed economies than among themselves [Syriopoulos 2004]. Yang, Tapon and Sun, based on data for the period 1988-2002, examined correlations between the top eight stock markets for five industries. They concluded 
that in the period covered by the study correlation among individual countries increased, which was interpreted as the effect of globalisation but it had evolved and was unstable. It was noted that correlation was increasing when price volatility in stock markets was on the rise [Yang et al. 2006]. Studies also focused on the impact of economic integration on relationships among stock markets in different countries. It was found that intense bilateral trade relations increase the correlation of rates of return on indices, and the real fluctuation of exchange rates decreases it [Tavares 2009]. There were also analyses of relationships between stock indices in the emerging markets and the S\&P500. The US market was found to induce changes in the emerging markets, while reverse relationships were not observed [Ozdemir et al. 2009]. Demian examined the impact of EU accessionon cointegration between developed markets and markets from Central and Eastern Europe. He proved that the EU accession had little effect on the links among markets and pointed to financial and economic factors as being much more influential [Demian 2011]. Syllignakis and Kouretas demonstrated the especially powerful impact of the developed markets on the emerging markets in times of crisis. They concluded that stock exchanges in Central and Eastern Europe are exposed to the risk of external shocks [Syllignakis, Kouretas 2011]. By analysing the effect of stock indices in the US, UK, and Germany on the WIG and the WIG20, in 1999-2009, attention was drawn to the strong impact of the European financial centres [Augustyński 2011]. Evrim-Mandaci and Cagli investigated the relationships between the US stock market and eleven stock markets in Europe at different development levels. Analysis of daily data for 2005-2012 showed similar market performance without confirming any benefits of international diversification [Evrim-Mandaci, Cagli 2012]. Avdulaj, Barunik analysed the profitability of portfolio diversification for the Czech index PX and the German DAX. They showed that over the period 2008-2013 some benefits could be achieved from international diversification, which, however, were not stable time-wise. First, they were gradually increasing up to the end of 2009 to then start decreasing, which is indicative of the differences in economic performance of stock markets in individual countries in the aftermath of the crisis [Avdulaj, Barunik 2013]. They investigated the power of linkages among indices from Central Europe, the DAX and the S\&P500. Using daily quotes for the period 2004-2012, it was found that the relationships between emerging markets are sensitive to market performance and links between developed markets are stable [Doman, Doman 2013]. Analyses focused also on the relationships between the indices such as BUX, PX, WIG, and STOXX50, using multi-dimensional GARCH models and data for the years 2001-2011. Correlations between markets are strong, they intensified after EU accession and remained at unchanged levels during the financial crisis [Gjika, Horvath 2013]. For the period 2004-2014, after Poland joined the EU, interrelationships between the WIG and selected global indices were examined. Interrelationships with indices from Western Europe were relatively stronger than with those from Eastern Europe. Weakened interrelationships were observed after 2012 [Czapkiewicz, Jamer 
2015]. We also analysed correlation relationships between stock exchange indices. Relationships were confirmed for all the markets included in the study for 1999-2011. However, the strength of the links differed significantly and the length of time for which the studies were conducted was also a relevant factor. In shorter periods, the links between indices were usually stronger while clearly weakened relationships were observed for extended periods [Hołubowicz 2014]. Some analyses focus on the connections between stock quotes in associated stock exchanges. In the case of the French, Belgium, and Dutch stock exchanges brought together under the umbrella of the Euronext alliance, significant relationships and a long-term equilibrium mechanism have been confirmed [Prenzena 2016]. Finally, research also addressed the lack of synchronised data for stock quotes from individual markets. Baumohl and Vyrost showed that the mismatch between time series had an effect upon the results obtained from the Granger causality tests, which limited the number of significant relationships [Baumohl, Vyrost 2010].

The research goal proposed for the paper and the resultsobtained so far have prompted us propose three research hypotheses.

H1: Time series of some stock indices in selected countries of Western Europe, Central Europe and the Unites States are mutually cointegrated and exhibit long-term interrelationships.

$\mathrm{H} 2$ : Granger causality relationship has been confirmed for some stock indices in selected countries of Western Europe, Central Europe and the United States.

H3: Causality relationships and long-term interrelationships among some stock indices in selected countries of Western Europe, Central Europe and the United States changed in between the periods before and after the 2008 financial crisis.

\section{Research sample and methodology}

Relationship analysis for the stock indices was carried out on a sample comprising seven markets. The exercise focused on the links between the rates of return of selected developed stock markets and the stock exchanges in Central Europe. The developed markets were represented by the biggest European stock exchanges, the Paris Bourse and its CAC40 index, the Frankfurt Stock Exchange and its DAX30 index, the London Stock Exchange and its FTS100 index, and the United States stock market with its S\&P500 index. The group of Central European markets included three stock exchanges: the Budapest Stock Exchange with its BUX index, the Prague Stock Exchange with PX index and the Warsaw Stock Exchange with its WIG index. Interrelationships were investigated based on data containing daily closing prices, measured with analysed indices. The time series covered indices for the period between 31.12.1997 and 30.12.2016 and contained 4,925 observations. The specificity of individual markets caused a mismatch between the series of data which was the effect of bank holidays, official holidays or exceptional events, such as the 9/11 attacks. To eliminate the negative impact of the mismatch, the series were 
synchronised [Baumohl, Vyrost 2010]. To make individual time series equal, we assumed that the missing values will be replaced with average values from the neighbouring observations. Such coordinated series of daily closing rates of stock market indices became the basis to identify weekly rates of return. We obtained 985 weekly rates of return for each index.

In order to compare the performance of indices over the period covered by the study, we presented them collectively in Figure 1. The data series were transformed to achieve an identical transformation scale. We assumed that the value of each index on 31.12.1997 was 1.

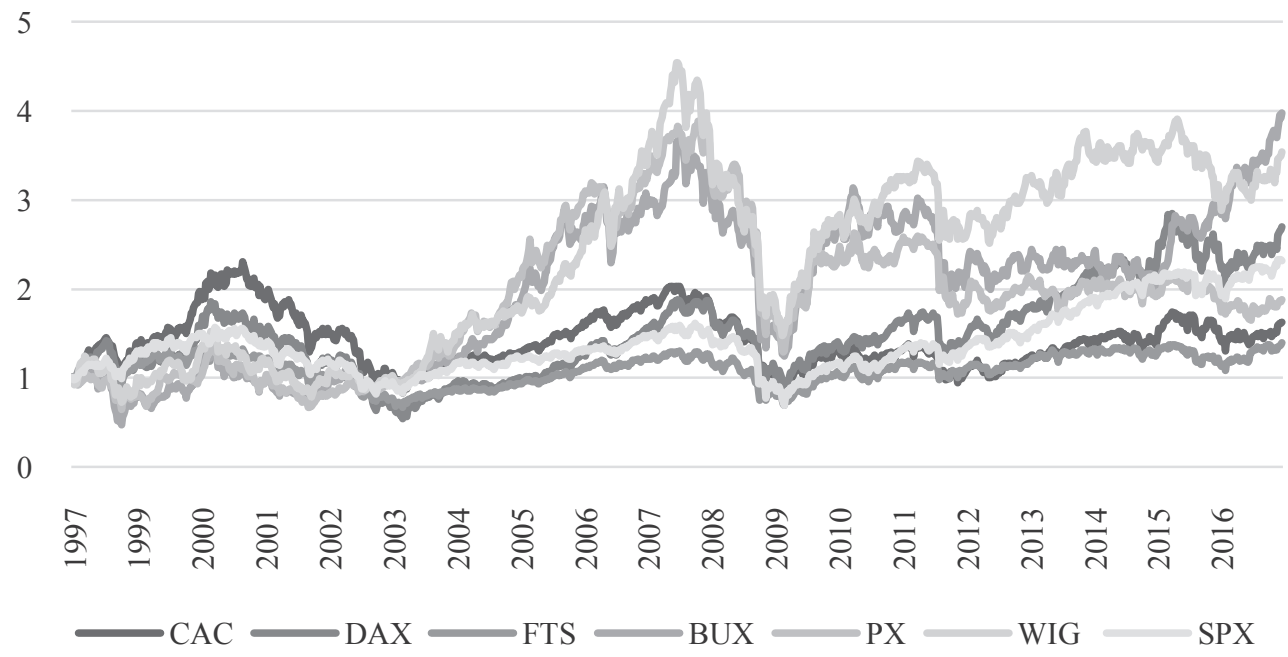

Fig. 1. Stock market indices (31.12.1997-30.12.2016)

Source: own elaboration.

Even a superficial analysis of the performance of the indices over time reveals some differences. Until 2009 the indices performed in a rather similar way but later a significant differentiation can be observed when it comes to changes in the stock market situation in individual markets. For instance, there are periods lasting for several months when some markets benefit and some lose. Presumably that is the effect of the global financial crisis, which reached its peak in 2008. The rapid and very deep downturn forced central banks to adopt a series of non-standard instruments of money creation, which some time later was reflected in the prices of assets in financial markets. The lack of coordination between what central banks were doing and the different rate at which individual countries managed to overcome the crisis resulted in the different performance of stock market indices. That is why when analyzing the mutual impact of the stock market indices, we decided to split the research period into before and after the crisis. In such cases we need to identify 
the cut-off date. In this study we decided that the period before "the global crisis" covers quotes between 31.12.1997 and 25.08.2006, while the second one starts on 1.09.2006 and goes on until 31.12.2016. The first consequences of the approaching crisis emerged in the financial market in July and August 2007 while some signs of increasing disequilibrium had been visible even earlier, which is why the decision was made to choose August 2006 as the cut-off date for the series covered by the study. As a result, in the first examined period we skipped over several thousand quotes directly preceding the crash in the financial markets, which at that moment could have been already under the influence of the worsening performance of the property market in the United States.

The date of the split of the examined series was selected to take account of the impact of EU accession of Central European countries, which effectively took place two years earlier. Demian claims that EU accession did not influence dependences amongst financial markets in individual countries [Demian 2011]. However it seems that a longer period of the study would help in noticing new relationships between the markets. The abolition of administrative barriers and advancing economic integration could have changed the dependences and impact capital transfers between the markets.

The division of the research period was also subject to the structural break test [Chow 1960]. The Chow breakpoint showed the lack of stability of indices and justified the division.

Table 1. Results of the Chow breakpoint test

\begin{tabular}{|l|r|l|l|}
\hline F-statistic & 73.8974 & Prob. F(7, 972) & 0.0000 \\
\hline Log likelihood ratio & 420.7202 & Prob. Chi-square (7) & 0.0000 \\
\hline Wald statistic & 517.2825 & Prob. Chi-square (7) & 0.0000 \\
\hline
\end{tabular}

Null hypothesis: no breaks at specified breakpoints.

Source: own elaboration.

The investigation of the changes in the indices helped us to carry out a general analysis of the dynamics of the changes in the surveyed period (Table 2). Stock markets are usually highly volatile and unstable, which was also observed in the years covered by the study. Nineteen annual rates of return were calculated which allowed comparing the growth rate for indices and the volatility of stock market performance in consecutive years. For instance, the AGR increased spectacularly by over 30\% in 1999 at the peak of the Internet boom or in 2009 when markets recovered after the earlier break down. Yet very significant drops were also visible; in 2008 the indices lost on average as much as $44 \%$. Significant differences were also observed between the indices. When it comes to the expected rate of return from different stock markets, investors are guided by the primary relationship between risk and income. The smaller the market and the more unstable the economy, the higher the 
Table 2. Stock market price indices

\begin{tabular}{|c|c|c|c|c|c|c|c|c|}
\hline Year & CAC & DAX & FTS & BUX & PX & WIG & SPX & AGR \\
\hline 1997 & $\begin{array}{c}2998.9 \\
-\end{array}$ & $\begin{array}{c}4294.3 \\
-\end{array}$ & $\begin{array}{c}5135.5 \\
-\end{array}$ & $\begin{array}{c}8068.9 \\
-\end{array}$ & $\begin{array}{c}492.5 \\
-\end{array}$ & $\begin{array}{c}14668.0 \\
-\end{array}$ & $\begin{array}{c}970.4 \\
-\end{array}$ & - \\
\hline 1998 & $\begin{array}{l}3942.7 \\
(31.5)\end{array}$ & $\begin{array}{l}5002.4 \\
(16.5)\end{array}$ & $\begin{array}{l}5882.6 \\
(14.6)\end{array}$ & $\begin{array}{r}6307.7 \\
(-21.8)\end{array}$ & $\begin{array}{c}394.2 \\
(-20.0)\end{array}$ & $\begin{array}{l}12795.6 \\
(-12.8)\end{array}$ & $\begin{array}{l}1229.2 \\
(26.7)\end{array}$ & 4.9 \\
\hline 1999 & $\begin{array}{c}5958.3 \\
(51.1)\end{array}$ & $\begin{array}{l}6958.1 \\
(39.1)\end{array}$ & $\begin{array}{l}6930.2 \\
(17.8)\end{array}$ & $\begin{array}{l}8819.5 \\
(39.8)\end{array}$ & $\begin{array}{l}489.7 \\
(24.2)\end{array}$ & $\begin{array}{c}18083.6 \\
(41.3)\end{array}$ & $\begin{array}{l}1469.3 \\
(19.5)\end{array}$ & 33.3 \\
\hline 2000 & $\begin{array}{l}5926.4 \\
(-0.5)\end{array}$ & $\begin{array}{l}6433.6 \\
(-7.5)\end{array}$ & $\begin{array}{l}6222.5 \\
(-10.2)\end{array}$ & $\begin{array}{l}7849.8 \\
(-11.0)\end{array}$ & $\begin{array}{l}478.5 \\
(-2.3)\end{array}$ & $\begin{array}{c}17847.6 \\
(-1.3)\end{array}$ & $\begin{array}{c}1320.3 \\
(-10.1)\end{array}$ & -6.1 \\
\hline 2001 & $\begin{array}{l}4624.6 \\
(-22.0) \\
\end{array}$ & $\begin{array}{l}5160.1 \\
(-19.8) \\
\end{array}$ & $\begin{array}{l}5217.4 \\
(-16.2) \\
\end{array}$ & $\begin{array}{l}7131.1 \\
(-9.2) \\
\end{array}$ & $\begin{array}{c}394.6 \\
(-17.5) \\
\end{array}$ & $\begin{array}{l}13922.2 \\
(-22.0)\end{array}$ & $\begin{array}{r}1148.1 \\
(-13.0) \\
\end{array}$ & -17.1 \\
\hline 2002 & $\begin{array}{r}3063.9 \\
(-33.8) \\
\end{array}$ & $\begin{array}{r}2892.6 \\
(-43.9) \\
\end{array}$ & $\begin{array}{l}3940.4 \\
(-24.5) \\
\end{array}$ & $\begin{array}{c}7798.3 \\
(9.4) \\
\end{array}$ & $\begin{array}{l}460.7 \\
(16.8) \\
\end{array}$ & $\begin{array}{c}14366.7 \\
(3.2) \\
\end{array}$ & $\begin{array}{c}879.8 \\
(-23.4) \\
\end{array}$ & -13.7 \\
\hline 2003 & $\begin{array}{c}3557.9 \\
(16.1)\end{array}$ & $\begin{array}{c}3965.2 \\
(37.1)\end{array}$ & $\begin{array}{l}4476.9 \\
(13.6)\end{array}$ & $\begin{array}{c}9380.0 \\
(20.3)\end{array}$ & $\begin{array}{l}659.1 \\
(43.1)\end{array}$ & $\begin{array}{c}20820.1 \\
(44.9)\end{array}$ & $\begin{array}{l}1111.9 \\
(26.4)\end{array}$ & 28.8 \\
\hline 2004 & $\begin{array}{c}3821.2 \\
(7.4)\end{array}$ & $\begin{array}{c}4256.1 \\
(7.3)\end{array}$ & $\begin{array}{c}4814.3 \\
(7.5)\end{array}$ & $\begin{array}{c}14742.6 \\
(57.2)\end{array}$ & $\begin{array}{l}1032.0 \\
(56.6)\end{array}$ & $\begin{array}{c}26636.2 \\
(27.9)\end{array}$ & $\begin{array}{l}1211.9 \\
(9.00)\end{array}$ & 24.7 \\
\hline 2005 & $\begin{array}{l}4715.2 \\
(23.4)\end{array}$ & $\begin{array}{c}5408.3 \\
(27.1) \\
\end{array}$ & $\begin{array}{l}5618.8 \\
(16.7) \\
\end{array}$ & $\begin{array}{c}20784.7 \\
(41.0) \\
\end{array}$ & $\begin{array}{l}1473.0 \\
(42.7) \\
\end{array}$ & $\begin{array}{c}35600.8 \\
(33.7) \\
\end{array}$ & $\begin{array}{c}1248.3 \\
(3.0) \\
\end{array}$ & 26.8 \\
\hline 2006 & $\begin{array}{l}5541.8 \\
(17.5) \\
\end{array}$ & $\begin{array}{l}6596.9 \\
(22.0) \\
\end{array}$ & $\begin{array}{c}6220.8 \\
(10.7) \\
\end{array}$ & $\begin{array}{c}24874.4 \\
(19.7) \\
\end{array}$ & $\begin{array}{c}1588.9 \\
(7.9)\end{array}$ & $\begin{array}{c}50411.8 \\
(41.6) \\
\end{array}$ & $\begin{array}{l}1418.3 \\
(13.6)\end{array}$ & 19.0 \\
\hline 2007 & $\begin{array}{c}5614.1 \\
(1.3)\end{array}$ & $\begin{array}{l}8067.3 \\
(22.3)\end{array}$ & $\begin{array}{c}6456.9 \\
(3.8)\end{array}$ & $\begin{array}{c}26235.6 \\
(5.5)\end{array}$ & $\begin{array}{l}1815.1 \\
(14.2)\end{array}$ & $\begin{array}{c}55648.5 \\
(10.4)\end{array}$ & $\begin{array}{c}1468.4 \\
(3.5)\end{array}$ & 8.7 \\
\hline 2008 & $\begin{array}{l}3218.0 \\
(-42.7)\end{array}$ & $\begin{array}{l}4810.2 \\
(-40.4)\end{array}$ & $\begin{array}{l}4434.2 \\
(-31.3)\end{array}$ & $\begin{array}{l}12241.7 \\
(-53.3)\end{array}$ & $\begin{array}{c}858.2 \\
(-52.7)\end{array}$ & $\begin{array}{c}27228.6 \\
(-51.1)\end{array}$ & $\begin{array}{c}903.3 \\
(-38.5)\end{array}$ & -44.3 \\
\hline 2009 & $\begin{array}{c}3936.3 \\
(22.3)\end{array}$ & $\begin{array}{l}5957.4 \\
(23.9)\end{array}$ & $\begin{array}{l}5412.9 \\
(22.1)\end{array}$ & $\begin{array}{c}21227.0 \\
(73.4)\end{array}$ & $\begin{array}{l}1117.3 \\
(30.2)\end{array}$ & $\begin{array}{c}39986.0 \\
(46.9)\end{array}$ & $\begin{array}{l}1115.1 \\
(23.5)\end{array}$ & 34.6 \\
\hline 2010 & $\begin{array}{l}3804.8 \\
(-3.3) \\
\end{array}$ & $\begin{array}{l}6914.2 \\
(16.1) \\
\end{array}$ & $\begin{array}{c}5899.9 \\
(9.0) \\
\end{array}$ & $\begin{array}{c}21327.1 \\
(0.5) \\
\end{array}$ & $\begin{array}{c}1224.8 \\
(9.6) \\
\end{array}$ & $\begin{array}{c}47489.9 \\
(18.8) \\
\end{array}$ & $\begin{array}{l}1257.6 \\
(12.8)\end{array}$ & 9.1 \\
\hline 2011 & $\begin{array}{l}3159.8 \\
(-17.0)\end{array}$ & $\begin{array}{c}5898.4 \\
(-14.7)\end{array}$ & $\begin{array}{l}5572.3 \\
(-5.6)\end{array}$ & $\begin{array}{l}16974.2 \\
(-20.4)\end{array}$ & $\begin{array}{c}911.1 \\
(-25.6)\end{array}$ & $\begin{array}{c}37595.4 \\
(-20.8)\end{array}$ & $\begin{array}{c}1257.6 \\
(0.0)\end{array}$ & -14.9 \\
\hline 2012 & $\begin{array}{l}3641.1 \\
(15.2)\end{array}$ & $\begin{array}{l}7612.4 \\
(29.1) \\
\end{array}$ & $\begin{array}{c}5897.8 \\
(5.8) \\
\end{array}$ & $\begin{array}{c}18173.2 \\
(7.1) \\
\end{array}$ & $\begin{array}{l}1038.7 \\
(14.0) \\
\end{array}$ & $\begin{array}{c}47460.6 \\
(26.2) \\
\end{array}$ & $\begin{array}{l}1426.2 \\
(13.4) \\
\end{array}$ & 15.8 \\
\hline 2013 & $\begin{array}{l}4296.0 \\
(18.0)\end{array}$ & $\begin{array}{c}9552.2 \\
(25.5)\end{array}$ & $\begin{array}{l}6749.1 \\
(14.4)\end{array}$ & $\begin{array}{c}18564.1 \\
(2.2)\end{array}$ & $\begin{array}{l}989.0 \\
(-4.8)\end{array}$ & $\begin{array}{c}51284.3 \\
(8.1)\end{array}$ & $\begin{array}{l}1848.4 \\
(29.6)\end{array}$ & 13.3 \\
\hline 2014 & $\begin{array}{l}4272.8 \\
(-0.5)\end{array}$ & $\begin{array}{c}9805.6 \\
(2.7)\end{array}$ & $\begin{array}{l}6566.1 \\
(-2.7)\end{array}$ & $\begin{array}{l}16634.0 \\
(-10.4)\end{array}$ & $\begin{array}{l}946.7 \\
(-4.3) \\
\end{array}$ & $\begin{array}{c}51416.1 \\
(0.3)\end{array}$ & $\begin{array}{c}2058.9 \\
(11.4)\end{array}$ & -0.5 \\
\hline 2015 & $\begin{array}{c}4637.1 \\
(8.5)\end{array}$ & $\begin{array}{c}10743.0 \\
(9.6)\end{array}$ & $\begin{array}{l}6242.3 \\
(-4.9)\end{array}$ & $\begin{array}{c}23920.7 \\
(43.8)\end{array}$ & $\begin{array}{c}956.3 \\
(1.0)\end{array}$ & $\begin{array}{c}46467.4 \\
(-9.6)\end{array}$ & $\begin{array}{l}2044.0 \\
(-0.7)\end{array}$ & 6.8 \\
\hline 2016 & $\begin{array}{c}4862.3 \\
(4.9)\end{array}$ & $\begin{array}{c}11481.1 \\
(6.9)\end{array}$ & $\begin{array}{l}7142.8 \\
(14.4)\end{array}$ & $\begin{array}{c}32003.1 \\
(33.8)\end{array}$ & $\begin{array}{l}921.6 \\
(-3.6)\end{array}$ & $\begin{array}{c}51754.0 \\
(11.4)\end{array}$ & $\begin{array}{c}2238.8 \\
(9.5)\end{array}$ & 11.0 \\
\hline AGR & 5.1 & 8.3 & 2.9 & 12.0 & 6.8 & 10.4 & 6.1 & \\
\hline
\end{tabular}

Notes: figures in parentheses indicate annual growth rates; AGR - annual growth rate.

Source: own elaboration. 
risk and expected rate of return. This means that the developed markets in Western Europe and in the United States should have generated lower rates of return than the emerging markets in Central Europe. Generally acclaimed relationships between risk and the rate of return were observed in the surveyed period. The highest annual rates of return were reported for the markets in Hungary and in Poland with the German market ranking third and the Czech stock exchange achieving an average growth only slightly higher than the SPX index. Nevertheless, we must stress that the investigation focused not only on the dynamics of changes in the indices but it also covered the interrelationships between these changes; hence in the next stage of the study we analysed the degree of integration of the examined time series.

To examine the order of integration of time series covered by the study we used the unit root tests ADF and KPSS. The test was carried out for two sub-periods, before and after the crisis. The series of stock market indices used in the analysis were log-transformed. Such transformations are often used in research studies as they may reduce the grouping of variances and make data conform more closely to the normal distribution. We investigated the time series of logarithms of the stock indices and the first differences of the original index series, quoted on a weekly basis. We calculated the weekly logarithmic rates of return Weekly rates of return were computed based on the value of indices at the close of business on Friday in weeks $t$ and $t-1$.

$$
r_{t}=y_{t}-y_{t-1}=\ln \left(\frac{y_{t}}{y_{t-1}}\right) \text {, }
$$

$y_{t}-$ index in week $t ; y_{t-1}-$ index in week $t-1$.

First, we performed the ADF test [Dickey, Fuller 1979] and then, to confirm the order of integration of the series, the indices underwent the KPSS test [Kwiatkowski et al.1992]. The results are presented in Tables 3 and 4. The tests demonstrated that the examined series are integrated of order 1 . The time series of log-transformed indices were non-stationary in their levels and stationary in their first difference.

Table 3. Results of stationarity tests in the period 1.1998-8.2006

\begin{tabular}{|c|c|c|c|c|c|c|}
\hline \multirow{2}{*}{ Variable } & \multicolumn{4}{|c|}{ ADF test } & \multicolumn{2}{c|}{ KPSS test } \\
\cline { 2 - 7 } & \multicolumn{2}{|c|}{ level } & \multicolumn{2}{c|}{$\begin{array}{c}\text { test statistic } \\
\text { critical value } \\
(\alpha=0.05) 0.462\end{array}$} \\
\cline { 2 - 7 } & test statistic & $p$ & test statistic & $p$ & 1 level & $\begin{array}{c}\text { first } \\
\text { difference }\end{array}$ \\
\hline 1 & 2 & 3 & 4 & 5 & 6 & 7 \\
\hline CAC & -1.7619 & 0.3994 & -21.6579 & 0.0000 & 1.175 & 0.233 \\
\hline DAX & -1.3681 & 0.5986 & -15.5069 & 0.0000 & 2.007 & 0.164 \\
\hline
\end{tabular}


Table 3. cont.

\begin{tabular}{|l|c|c|c|c|c|c|}
\hline \multicolumn{1}{|c|}{1} & 2 & 3 & 4 & 5 & 6 & 7 \\
\hline FTS & -1.2943 & 0.6346 & -9.0125 & 0.0000 & 2.940 & 0.178 \\
\hline BUX & -0.1089 & 0.9468 & -8.4726 & 0.0000 & 5.336 & 0.201 \\
\hline PX & 0.4276 & 0.9839 & -19.9651 & 0.0000 & 5.415 & 0.325 \\
\hline WIG & 0.0647 & 0.9627 & -8.9839 & 0.0000 & 4.704 & 0.215 \\
\hline SPX & -1.9458 & 0.3111 & -8.6461 & 0.0000 & 1.158 & 0.136 \\
\hline
\end{tabular}

ADF test - null hypothesis: there is a unit root a $=1$; process I (1); KPSS test - null hypothesis: a stationary process.

Source: own elaboration.

Table 4. Results of stationarity tests in the period 9.2006-12.2016

\begin{tabular}{|l|c|c|c|c|c|c|}
\hline \multirow{2}{*}{ Variable } & \multicolumn{2}{|c|}{ ADF test } & \multicolumn{2}{c|}{ KPSS test } \\
\cline { 2 - 7 } & \multicolumn{2}{|c|}{ level } & \multicolumn{2}{c|}{$\begin{array}{c}\text { test statistic } \\
\text { fritical value } \\
(\alpha=0.05) 0.462\end{array}$} \\
\cline { 2 - 7 } & test statistic & $p$ & test statistic & $p$ & level & $\begin{array}{c}\text { first } \\
\text { difference }\end{array}$ \\
\hline CAC & -2.1445 & 0.2273 & -18.0132 & 0.0000 & 1.271 & 0.170 \\
\hline DAX & -0.6872 & 0.8482 & -8.3725 & 0.0000 & 5.144 & 0.077 \\
\hline FTS & -1.6050 & 0.4800 & -5.7035 & 0.0000 & 2.667 & 0.085 \\
\hline BUX & -1.7237 & 0.4192 & -7.0631 & 0.0000 & 0.580 & 0.165 \\
\hline PX & -1.8569 & 0.3532 & -9.1366 & 0.0000 & 3.847 & 0.050 \\
\hline WIG & -2.3049 & 0.1704 & -5.0679 & 0.0000 & 1.068 & 0.073 \\
\hline SPX & -0.7338 & 0.8365 & -4.6053 & 0.0001 & 5.137 & 0.188 \\
\hline
\end{tabular}

ADF test - null hypothesis: there is a unit root a $=1$; process I (1); KPSS test - null hypothesis: a stationary process.

Source: own elaboration.

Next we examined interrelationships between the indices. Cointegration tests were conducted following the Johansen test procedure using the trace test and the maximum eigenvalue test statistic [Johansen 1988]. The obtained results provided grounds for selecting models to perform causality tests. Granger causality means that variable $\mathrm{X}$ is causal to variable $\mathrm{Y}$ if the current values of $\mathrm{Y}$ can be predicted more accurately based on past values of variable X [Granger 1969]. Granger causality is tested using vector autoregressive (VAR) models and vector error correction models (VECM), depending on cointegration tests and stationarity analysis of time series [Engle, Granger 1987]. The VAR model is used to examine Granger causality in stationary series while to conduct Granger causality tests for non-stationary but cointegrated series, we need to use the VECM. If the series of levels are nonstationary and non-cointegrated, a Granger causality test is performed using the 
VAR model for the series of first differences, however, under the assumption of their stationarity.

The models for the investigated series in the two sub-periods that have been selected following stationarity and cointegration tests were error correction or vector autoregression models for variable increments. The examined relationships were described with the following VECM model:

$$
\begin{aligned}
& r_{K t}=a_{K 0}+\sum_{i=1}^{p} a_{K 1 i} r_{K t-i}+\sum_{i=1}^{p} a_{K 2 i} r_{L t-i}+b_{K} E C T_{t-1}+\varepsilon_{K t}, \\
& r_{L t}=a_{L 0}+\sum_{i=1}^{p} a_{L 1 i} r_{L t-i}+\sum_{i=1}^{p} a_{L 2 i} r_{K t-i}+b_{L} E C T_{t-1}+\varepsilon_{L t},
\end{aligned}
$$

where: $r_{K t}$ - logarithmic rate of return for stock market index $K ; r_{L t}-$ logarithmic rate of return for stock market index $L ; a_{K 0}, a_{L 0}$ - constant terms; $p$ - lag order for variables $r_{K t}$ and $r_{L t} ; a_{K 1 i}, a_{K 2 i}, a_{L 1 i}, a_{L 2 i}$ - short run relationship indicators; $b_{K}, b_{L}-$ long run relationship indicators; $E C T_{t-1}$ - error correction term.

VAR for variable increments was represented by the formula:

$$
\begin{aligned}
& r_{K t}=a_{K 0}+\sum_{i=1}^{p} a_{K 1 i} r_{K t-i}+\sum_{i=1}^{p} a_{K 2 i} r_{L t-i}+\varepsilon_{K t} \\
& r_{L t}=a_{L 0}+\sum_{i=1}^{p} a_{L 1 i} r_{L t-i}+\sum_{i=1}^{p} a_{L 2 i} r_{K t-i}+\varepsilon_{L t}
\end{aligned}
$$

in which symbols were identical with those in the VECM.

In the last stage, we performed the Granger causality Wald test to examine causal relationships between the indices based on the estimated VECM and VAR models. Cointegration and estimates of parameters of models that describe interrelationships between the time series of stock market indices were investigated using the EViews software.

\section{Results}

When examining the changes in relationships between stock market indices produced by the 2008 financial crisis, we divided the time series into two periods: from January 1998 until August 2006 and from September 2006 until December 2016. For each of them we conducted a cointegration analysis for the indices included in the analysis and performed Granger causality tests. Following the above presented research methodology, we started with the Johansen test, which helped us choose the model to be used for relationship analysis. If a row of matrix in the Johansen test was 
Table 5. Results of the Johansen cointegration test in the period 1.1998-8.2006

\begin{tabular}{|c|c|c|c|c|c|c|}
\hline \multirow{2}{*}{ Indices } & \multirow{2}{*}{ Rank } & \multirow{2}{*}{ Eigenvalue } & \multicolumn{4}{|c|}{ Cointegration test } \\
\hline & & & $\lambda_{\text {trace }}$ & $p$ & $\lambda_{\max }$ & $p$ \\
\hline \multirow{2}{*}{ CAC-DAX } & 0 & 0.03094 & 15.983 & 0.0406 & 14.049 & 0.0522 \\
\hline & 1 & 0.00432 & 1.934 & 0.1643 & 1.934 & 0.1643 \\
\hline \multirow{2}{*}{ CAC-FTS } & 0 & 0.02350 & 10.968 & 0.0831 & 10.677 & 0.0615 \\
\hline & 1 & 0.00065 & 0.291 & 0.6620 & 0.291 & 0.6531 \\
\hline \multirow{2}{*}{ CAC-BUX } & 0 & 0.06361 & 33.479 & 0.0036 & 29.315 & 0.0007 \\
\hline & 1 & 0.00930 & 4.165 & 0.7187 & 4.165 & 0.7205 \\
\hline \multirow{2}{*}{ CAC-PX } & 0 & 0.01451 & 6.740 & 0.6137 & 6.561 & 0.5501 \\
\hline & 1 & 0.00040 & 0.178 & 0.6728 & 0.178 & 0.6728 \\
\hline \multirow{2}{*}{ CAC-WIG } & 0 & 0.04361 & 27.130 & 0.0325 & 21.147 & 0.0245 \\
\hline & 1 & 0.01333 & 5.983 & 0.4729 & 5.983 & 0.4740 \\
\hline \multirow{2}{*}{ CAC-SPX } & 0 & 0.46483 & 29.616 & 0.0001 & 21.276 & 0.0025 \\
\hline & 1 & 0.01848 & 8.340 & 0.0039 & 8.340 & 0.0039 \\
\hline \multirow{2}{*}{ DAX-FTS } & 0 & 0.03853 & 21.768 & 0.0042 & 17.643 & 0.0123 \\
\hline & 1 & 0.00915 & 4.125 & 0.0422 & 4.125 & 0.0422 \\
\hline \multirow{2}{*}{ DAX-BUX } & 0 & 0.04558 & 24.738 & 0.0671 & 20.805 & 0.0279 \\
\hline & 1 & 0.00878 & 3.933 & 0.7501 & 3.933 & 0.7519 \\
\hline \multirow{2}{*}{ DAX-PX } & 0 & 0.02070 & 10.571 & 0.5906 & 9.393 & 0.4050 \\
\hline & 1 & 0.00262 & 1.178 & 0.9123 & 1.178 & 0.9116 \\
\hline \multirow{2}{*}{ DAX-WIG } & 0 & 0.01575 & 8.490 & 0.7820 & 7.111 & 0.6614 \\
\hline & 1 & 0.00308 & 1.378 & 0.8819 & 1.380 & 0.8810 \\
\hline \multirow{2}{*}{ DAX-SPX } & 0 & 0.03247 & 20.213 & 0.0492 & 14.788 & 0.0731 \\
\hline & 1 & 0.01204 & 5.425 & 0.2487 & 5.425 & 0.2482 \\
\hline \multirow{2}{*}{ FTS-BUX } & 0 & 0.03302 & 17.259 & 0.4038 & 14.976 & 0.2008 \\
\hline & 1 & 0.00511 & 2.283 & 0.9341 & 2.283 & 0.9352 \\
\hline \multirow{2}{*}{ FTS-PX } & 0 & 0.01657 & 8.493 & 0.7818 & 7.500 & 0.6160 \\
\hline & 1 & 0.00221 & 0.992 & 0.9373 & 0.992 & 0.9367 \\
\hline \multirow{2}{*}{ FTS-WIG } & 0 & 0.02224 & 12.931 & 0.7448 & 10.031 & 0.6235 \\
\hline & 1 & 0.00648 & 2.900 & 0.8764 & 2.900 & 0.8779 \\
\hline \multirow{2}{*}{ FTS-SPX } & 0 & 0.03087 & 15.939 & 0.0412 & 13.922 & 0.0548 \\
\hline & 1 & 0.00453 & $2, .017$ & 0.1555 & 2.017 & 0.1555 \\
\hline \multirow{2}{*}{ BUX-PX } & 0 & 0.03424 & 18.189 & 0.0518 & 15.538 & 0.0825 \\
\hline & 1 & 0.00593 & 2.651 & 0.1035 & 2.651 & 0.1035 \\
\hline \multirow{2}{*}{ BUX-WIG } & 0 & 0.02511 & 11.453 & 0.1876 & 11.419 & 0.1356 \\
\hline & 1 & 0.00001 & 0.034 & 0.8528 & 0.034 & 0.8528 \\
\hline \multirow{2}{*}{ BUX-SPX } & 0 & 0.03357 & 18.673 & 0.3069 & 15.228 & 0.1866 \\
\hline & 1 & 0.00770 & 3.445 & 0.8132 & 3.445 & 0.8149 \\
\hline \multirow{2}{*}{ PX-WIG } & 0 & 0.03383 & 17.214 & 0.0713 & 15.454 & 0.0849 \\
\hline & 1 & 0.00391 & 1.760 & 0.1847 & 1.760 & 0.1847 \\
\hline \multirow{2}{*}{ PX-SPX } & 0 & 0.03126 & 17.777 & 0.3666 & 14.260 & 0.2453 \\
\hline & 1 & 0.00780 & 3.517 & 0.8042 & 3.517 & 0.8059 \\
\hline WUA SDY & 0 & 0.02752 & 15.002 & 0.5811 & 12.529 & 0.3798 \\
\hline WIU-SPX & 1 & 0.00549 & 2.473 & 0.9182 & 2.473 & 0.9194 \\
\hline
\end{tabular}

The null hypothesis for the trace test: the number of cointegration vectors is $r=r^{*}<k$; the alternative $r=k$. The null hypothesis for the "maximum eigenvalue" test: the number of cointegration vectors is $r=r^{*}$; the alternative $r=r^{*}+1$. Testing proceeds sequentially for $r^{*}=1$, 2, etc. and the first non-rejection of the null is taken as an estimate of $r$.

Source: own elaboration. 
equal to zero, we used the VAR model for variable increments, if a row was equal to one, we used the VECM model.

In the first investigated period before the crisis, the Johansen test revealed 11 cointegrations between the stock market indices (Table 5). Long-term interrelationships between the indices were particularly clear in developed markets. All of the indices from Western Europe included in our study, the CAC, DAX, FTS, and the United States index SPX, were cointegrated. This was indicative of the powerful long-term relationships and similar back-track performance of these stock markets in the investigated period. Long-term interrelationships for the markets in Central Europe were not so obvious. Cointegration was observed between the PX and the WIG as well as the PX and the BUX indices, while no meaningful long-term relationships were found between the Polish and Hungarian stock market indices. There were also some rather scarce interrelationships between the indices of the developed and the emerging markets. The BUX index was cointegrated with the French CAC and the German DAX while the WIG was cointegrated with the CAC. It showed weak long-term relationships between the stock market indices from Central Europe and the developed stock markets.

In investigating relationships between the stock market indices before the 2008 financial crisis, we also used the Granger causality analysis. The results are presented in Table 6. We managed to capture 7 bidirectional and 9 unidirectional relationships. Bidirectional causal relationships were observed mainly between the stock market indices in the developed markets. The only case when it was absent concerns the CAC and FTS indices. This means there are powerful causality links between the biggest stock markets in Western Europe and in the United States of America. Bidirectional causal relationships were also observed between the CAC and the BUX, as well as the CAC and the WIG. Notably, causality links between the stock market indices in Central Europe are rather limited. There were only two unidirectional relationships, where the BUX affected the PX and the PX affected the WIG. On top of that, we noted causal relationships between stock market indices in advanced economies and some stock market indices from Central European countries. Besides the above mentioned bidirectional relationships with the CAC index, there were also unidirectional relationships. In the Granger sense, the cause for the changes in the BUX and the WIG indices should be looked for in the DAX and the SPX indices. Unidirectional causal relationships were also reported for the FTS index. This inclined us to believe that in the period before the 2008 crisis, stock markets in Poland and in Hungary maintained rather close causal relationships with the stock markets in Western Europe and in the United States and responded to changes in the performance of the stock markets in advanced economies.

The next stage focused on examining long-term interrelationships between the stock indices from September 2006 to December 2016. The Johansen test revealed six cointegrations between the examined indices (Table 7). The number of long-term interrelationships was clearly smaller than the one observed before the crisis. Only 
Table 6. The causality test between stock market indices in the period 1.1998-8.2006

\begin{tabular}{|c|c|c|c|c|c|c|c|}
\hline \multirow{2}{*}{$\begin{array}{c}\text { Dependent } \\
\text { variables }\end{array}$} & \multicolumn{7}{|c|}{ Independent variables } \\
\hline & $\mathrm{CAC}$ & DAX & FTS & BUX & PX & WIG & SPX \\
\hline $\mathrm{CAC}$ & - & $\begin{array}{c}9.5284 \\
(0.0085) \\
* * *\end{array}$ & $\begin{array}{l}10.0920 \\
(0.1208)\end{array}$ & $\begin{array}{c}12.3915 \\
(0.0147) \\
* *\end{array}$ & $\begin{array}{c}0.0000 \\
(0.9955)\end{array}$ & $\begin{array}{c}35.2186 \\
(0.0000) \\
* * *\end{array}$ & $\begin{array}{c}16.4559 \\
(0.0009) \\
* * *\end{array}$ \\
\hline DAX & $\begin{array}{c}15.2917 \\
(0.0005) \\
* * *\end{array}$ & - & $\begin{array}{c}13.1408 \\
(0.0003) \\
* * *\end{array}$ & $\begin{array}{c}7.3408 \\
(0.1189)\end{array}$ & $\begin{array}{c}0.1248 \\
(0.7239)\end{array}$ & $\begin{array}{c}0.1042 \\
(0.7469)\end{array}$ & $\begin{array}{c}17.7000 \\
(0.0000) \\
* * *\end{array}$ \\
\hline FTS & $\begin{array}{c}38.3209 \\
(0.0000) \\
* * *\end{array}$ & $\begin{array}{c}4.3554 \\
(0.0369) \\
* *\end{array}$ & - & $\begin{array}{c}9.6294 \\
(0.0220) \\
* *\end{array}$ & $\begin{array}{c}0.0201 \\
(0.8873)\end{array}$ & $\begin{array}{c}2.4031 \\
(0.4931)\end{array}$ & $\begin{array}{c}13.8170 \\
(0.0168) \\
* *\end{array}$ \\
\hline BUX & $\begin{array}{c}10.0278 \\
(0.0400) \\
* *\end{array}$ & $\begin{array}{c}10.9108 \\
(0.0276) \\
* *\end{array}$ & $\begin{array}{c}2.8018 \\
(0.4232)\end{array}$ & - & $\begin{array}{c}3.9241 \\
(0.2698)\end{array}$ & $\begin{array}{c}1.5092 \\
(0.6801)\end{array}$ & $\begin{array}{c}6.7320 \\
(0.0809) \\
*\end{array}$ \\
\hline PX & $\begin{array}{c}0.0039 \\
(0.9502)\end{array}$ & $\begin{array}{c}0.2691 \\
(0.6039)\end{array}$ & $\begin{array}{c}0.5851 \\
(0.4443)\end{array}$ & $\begin{array}{c}34.5564 \\
(0.0000) \\
* * *\end{array}$ & - & $\begin{array}{c}0.7324 \\
(0.3921)\end{array}$ & $\begin{array}{c}0.8315 \\
(0.3618)\end{array}$ \\
\hline WIG & $\begin{array}{c}23.9588 \\
(0.0001) \\
* * *\end{array}$ & $\begin{array}{c}7.2821 \\
(0.0070) \\
* * *\end{array}$ & $\begin{array}{c}13.6884 \\
(0.0034) \\
* * *\end{array}$ & $\begin{array}{c}3.0410 \\
(0.3854)\end{array}$ & $\begin{array}{c}14.9753 \\
(0.0001) \\
* * *\end{array}$ & - & $\begin{array}{c}2.8585 \\
(0.0909) \\
*\end{array}$ \\
\hline SPX & $\begin{array}{c}8.5520 \\
(0.0359) \\
* *\end{array}$ & $\begin{array}{c}32.6783 \\
(0.0000) \\
* * *\end{array}$ & $\begin{array}{c}17.5182 \\
(0.0036) \\
* * *\end{array}$ & $\begin{array}{c}4.0666 \\
(0.2544)\end{array}$ & $\begin{array}{c}0.0475 \\
(0.8274)\end{array}$ & $\begin{array}{c}0.0847 \\
(0.7710)\end{array}$ & - \\
\hline
\end{tabular}

Notes: chi-square statistics for pairwise Granger causality tests; figures in parentheses indicate $p$-value; * - significant at the $10 \%$ level; ** - significant at the $5 \%$ level; *** - significant at the $1 \%$ level; the Granger causality test - carries out pairwise Granger causality tests and tests whether an endogenous variable can be treated as exogenous.

Source: own elaboration.

three cointegrations were found between the stock market indices in the advanced economies. Long-term interrelationships were found for the DAX and the CAC, the DAX and the FTS, as well as the DAX and the SPX. When it comes to the stock markets in Central Europe, no meaningful interrelationship was detected between the investigated stock indices. Yet we documented three cointegrations between the indices in the developed countries and the emerging markets. Long-term interrelationships were identified between the WIG and the DAX, the WIG and the SPX, as well as the PX and the DAX. The results of the analysis were indicative of the changes in the observed interrelationships between the stock markets that took place after the 2008 crisis, in particular in Western European countries and in the United States. It confirmed significant changes in the economic situation in individual stock markets. We may assume that this was triggered by the differences in the course of the financial crisis in individual countries. 
Table 7. Results of the Johansen cointegration test in the period 9.2006-12.2016

\begin{tabular}{|c|c|c|c|c|c|c|}
\hline \multirow{2}{*}{ Indices } & \multirow{2}{*}{ Rank } & \multirow{2}{*}{ Eigenvalue } & \multicolumn{4}{|c|}{ Cointegration test } \\
\hline & & & $\lambda_{\text {to }}$ & $p$ & $\lambda$ & $p$ \\
\hline \multirow{2}{*}{ CAC-DAX } & 0 & 0.21388 & 12.102 & 0.0537 & 11.545 & 0.0426 \\
\hline & 1 & 0.00104 & 0.557 & 0.5220 & 0.557 & 0.5152 \\
\hline \multirow{2}{*}{ CAC-FTS } & 0 & 0.01713 & 13.003 & 0.7394 & 9.225 & 0.7044 \\
\hline & 1 & 0.00705 & 3.778 & 0.7706 & 3.778 & 0.7724 \\
\hline \multirow{2}{*}{ CAC-BUX } & 0 & 0.00630 & 3.347 & 0.7915 & 3.345 & 0.7308 \\
\hline & 1 & 0.00000 & 0.002 & 0.9797 & 0.002 & 0.9769 \\
\hline \multirow{2}{*}{ CAC-PX } & 0 & 0.01812 & 14.624 & 0.6119 & 9.727 & 0.6544 \\
\hline & 1 & 0.00916 & 4.897 & 0.6175 & 4.897 & 0.6191 \\
\hline \multirow{2}{*}{ CAC-WIG } & 0 & 0.01339 & 7.235 & 0.3039 & 7.171 & 0.2406 \\
\hline & 1 & 0.00012 & 0.064 & 0.8601 & 0.064 & 0.8517 \\
\hline \multirow{2}{*}{ CAC-SPX } & 0 & 0.01270 & 10.945 & 0.8732 & 6.797 & 0.9032 \\
\hline & 1 & 0.00777 & 4.149 & 0.7209 & 4.149 & 0.7227 \\
\hline \multirow{2}{*}{ DAX-FTS } & 0 & 0.02467 & 14.546 & 0.0679 & 13.339 & 0.0682 \\
\hline & 1 & 0.00226 & 1.208 & 0.2718 & 1.208 & 0.2718 \\
\hline \multirow{2}{*}{ DAX-BUX } & 0 & 0.01047 & 7.478 & 0.9846 & 5.554 & 0.9614 \\
\hline & 1 & 0.00364 & 1.924 & 0.9594 & 1.924 & 0.9602 \\
\hline \multirow{2}{*}{ DAX-PX } & 0 & 0.01927 & 11.189 & 0.0764 & 10.195 & 0.0751 \\
\hline & 1 & 0.00189 & 0.993 & 0.3713 & 0.993 & 0.3678 \\
\hline \multirow{2}{*}{ DAX-WIG } & 0 & 0.03175 & 20.985 & 0.0196 & 17.229 & 0.0461 \\
\hline & 1 & 0.00700 & 3.756 & 0.0526 & 3.756 & 0.0526 \\
\hline \multirow{2}{*}{ DAX-SPX } & 0 & 0.03272 & 17.895 & 0.0197 & 17.732 & 0.0119 \\
\hline & 1 & 0.00031 & 0.162 & 0.6869 & 0.162 & 0.6870 \\
\hline \multirow{2}{*}{ FTS-BUX } & 0 & 0.00530 & 2.845 & 0.8538 & 2.790 & 0.8118 \\
\hline & 1 & 0.00011 & 0.055 & 0.8718 & 0.055 & 0.8636 \\
\hline \multirow{2}{*}{ FTS-PX } & 0 & 0.01672 & 8.996 & 0.3725 & 8.769 & 0.3130 \\
\hline & 1 & 0.00044 & 0.227 & 0.6336 & 0.227 & 0.6336 \\
\hline \multirow{2}{*}{ FTS-WIG } & 0 & 0.05669 & 34.457 & 0.0001 & 31.162 & 0.0001 \\
\hline & 1 & 0.00615 & 3.296 & 0.0695 & 3.296 & 0.0695 \\
\hline \multirow{2}{*}{ FTS-SPX } & 0 & 0.01501 & 7.945 & 0.4786 & 7.939 & 0.3935 \\
\hline & 1 & 0.00001 & 0.006 & 0.9401 & 0.005 & 0.9402 \\
\hline \multirow{2}{*}{ BUX-PX } & 0 & 0.01152 & 6.133 & 0.6835 & 6.103 & 0.6064 \\
\hline & 1 & 0.00001 & 0.029 & 0.8641 & 0.029 & 0.8641 \\
\hline \multirow{2}{*}{ BUX-WIG } & 0 & 0.00867 & 6.236 & 0.9954 & 4.588 & 0.9855 \\
\hline & 1 & 0.00312 & 1.648 & 0.9743 & 1.648 & 0.9750 \\
\hline \multirow{2}{*}{ BUX-SPX } & 0 & 0.01018 & 7.510 & 0.9841 & 5.410 & 0.9661 \\
\hline & 1 & 0.00396 & 2.100 & 0.9478 & 2.100 & 0.9488 \\
\hline \multirow{2}{*}{ PX-WIG } & 0 & 0.02661 & 20.047 & 0.2277 & 14.185 & 0.2504 \\
\hline & 1 & 0.01108 & 5.862 & 0.4882 & 5.862 & 0.4894 \\
\hline \multirow{2}{*}{ PX-SPX } & 0 & 0.01605 & 9.436 & 0.1458 & 8.575 & 0.1433 \\
\hline & 1 & 0.00162 & 0.862 & 0.4098 & 0.862 & 0.4055 \\
\hline & 0 & 0.02245 & 15.818 & 0.5150 & 11.963 & 0.4312 \\
\hline WIG-SPX & 1 & 0.00729 & 3.855 & 0.7604 & 3.855 & 0.7622 \\
\hline
\end{tabular}

The null hypothesis for the trace test: the number of cointegration vectors is $r=r^{*}<k$; the alternative $r=k$. The null hypothesis for the "maximum eigenvalue" test: the number of cointegration vectors is $r=r^{*}$; the alternative $r=r^{*}+1$. Testing proceeds sequentially for $r^{*}=1,2$, etc. and the first non-rejection of the null is taken as an estimate of $r$.

Source: own elaboration. 
Table 8. The causality test between stock market indices in the period 9.2006-12.2016

\begin{tabular}{|c|c|c|c|c|c|c|c|}
\hline \multirow{2}{*}{$\begin{array}{c}\text { Dependent } \\
\text { variables }\end{array}$} & \multicolumn{7}{|c|}{ Independent variables } \\
\hline & $\mathrm{CAC}$ & DAX & FTS & BUX & PX & WIG & SPX \\
\hline $\mathrm{CAC}$ & - & $\begin{array}{c}55.1818 \\
(0.0000) \\
* * *\end{array}$ & $\begin{array}{c}0.9944 \\
(0.3187)\end{array}$ & $\begin{array}{c}3.2226 \\
(0.6657)\end{array}$ & $\begin{array}{c}3.3222 \\
(0.1899)\end{array}$ & $\begin{array}{c}2.5160 \\
(0.2842)\end{array}$ & $\begin{array}{c}9.7987 \\
(0.0204) \\
* *\end{array}$ \\
\hline $\mathrm{DAX}$ & $\begin{array}{c}48.0147 \\
(0.0000) \\
* * *\end{array}$ & - & $\begin{array}{c}14.3991 \\
(0.0024) \\
* * *\end{array}$ & $\begin{array}{c}5.4644 \\
(0.4858)\end{array}$ & $\begin{array}{c}41.9556 \\
(0.0000) \\
* * *\end{array}$ & $\begin{array}{c}54.7662 \\
(0.0000) \\
* * *\end{array}$ & $\begin{array}{c}51.3351 \\
(0.0000) \\
* * *\end{array}$ \\
\hline FTS & $\begin{array}{c}0.0033 \\
(0.9543)\end{array}$ & $\begin{array}{c}44.8558 \\
(0.0000) \\
* * *\end{array}$ & - & $\begin{array}{l}12.5358 \\
(0.1848)\end{array}$ & $\begin{array}{c}26.5842 \\
(0.0218) \\
* *\end{array}$ & $\begin{array}{c}62.1785 \\
(0.0000) \\
* * *\end{array}$ & $\begin{array}{c}28.3512 \\
(0.0008) \\
* * *\end{array}$ \\
\hline BUX & $\begin{array}{c}18.8830 \\
(0.0020) \\
* * *\end{array}$ & $\begin{array}{c}16.1819 \\
(0.0128) \\
* *\end{array}$ & $\begin{array}{c}24.3543 \\
(0.0038) \\
* * *\end{array}$ & - & $\begin{array}{c}19.1158 \\
(0.0078) \\
* * *\end{array}$ & $\begin{array}{c}14.7766 \\
(0.0390) \\
* *\end{array}$ & $\begin{array}{c}14.2677 \\
(0.0140) \\
* *\end{array}$ \\
\hline PX & $\begin{array}{c}0.5425 \\
(0.7624)\end{array}$ & $\begin{array}{c}16.9187 \\
(0.0762) \\
*\end{array}$ & $\begin{array}{c}25.5423 \\
(0.0296) \\
* *\end{array}$ & $\begin{array}{c}14.7217 \\
(0.0397) \\
* *\end{array}$ & - & $\begin{array}{c}21.3870 \\
(0.0062) \\
* * *\end{array}$ & $\begin{array}{c}7.5698 \\
(0.1087)\end{array}$ \\
\hline WIG & $\begin{array}{c}0.8913 \\
(0.6404)\end{array}$ & $\begin{array}{c}0.7151 \\
(0.3978)\end{array}$ & $\begin{array}{c}1.4541 \\
(0.2279)\end{array}$ & $\begin{array}{c}13.8744 \\
(0.0535) \\
*\end{array}$ & $\begin{array}{c}21.2817 \\
(0.0064) \\
* * *\end{array}$ & - & $\begin{array}{c}19.9986 \\
(0.0056) \\
* * *\end{array}$ \\
\hline SPX & $\begin{array}{c}25.7634 \\
(0.0000) \\
* * *\end{array}$ & $\begin{array}{c}5.1545 \\
(0.0760) \\
*\end{array}$ & $\begin{array}{c}53.3925 \\
(0.0000) \\
* * *\end{array}$ & $\begin{array}{c}6.4521 \\
(0.2647)\end{array}$ & $\begin{array}{c}34.3751 \\
(0.0000) \\
* * *\end{array}$ & $\begin{array}{c}26.9535 \\
(0.0003) \\
* * *\end{array}$ & - \\
\hline
\end{tabular}

Notes: chi-square statistics for pairwise Granger causality tests; figures in parentheses indicate $p$-value; * - significant at the $10 \%$ level; ** - significant at the $5 \%$ level; *** - significant at the $1 \%$ level; the Granger causality test - carries out pairwise Granger causality tests and tests whether an endogenous variable can be treated as exogenous.

Source: own elaboration.

The Granger causality carried out in the second research period showed eleven bidirectional and seven unidirectional relationships (Table 8). For causal relationships we observed some differences between the indices compared to the period from before the 2008 crisis. The number of causal relationships slightly increased and major changes took place in the stock exchanges from Central Europe. Bidirectional causal relationships were found for the BUX, the PX, and the WIG, while in the previous research period no bidirectional relationship was observed. Bidirectional relationships reoccurred between the stock markets in Western Europe and in the United States, confirming strong mutual causality between the CAC, the DAX, and the SPX existing regardless of the economic situation. Our analysis revealed some changes in the Granger causality relationships between the stock market indices in Central Europe and in advanced economies. The stock market indices from developed countries - Western Europe and the United States - clearly influenced the BUX index and were reasons behind its fluctuations. In turn, changes in the 
PX index were induced by the DAX. Bidirectional relationships were observed between the PX and the FTS as well as the WIG and SPX indices. The observed causal relationships between stock indices in developed economies and in Central Europe emerged as a new phenomenon triggered, in terms of Granger causality, by the PX and WIG indices. Summing up observations in the second research period we may say that causal relationships between the stock indices in Western Europe and in the United States have been maintained, while many changes were observed in the relationships concerning the markets in Central Europe. In all three emerging markets we identified mutual bidirectional relationships indicative of stronger causal relationships. The number of causal relationships between the stock markets in the developed economies and in Central Europe increased testifying to the advancing economic integration.

\section{Conclusion}

When analyzing interrelationships between selected stock market indices in Western Europe, Central Europe, and in the United States we divided the time series into two periods: from January 1998 to August 2006, and from September 2006 to December 2016. The first period covered stock market quotes from before the financial crisis; the second one took account of the crisis and changes in the economic situation over the years following the crisis. Thus, we were able to compare changes in relationships between the indices in the analyzed periods. We performed a cointegration analysis following the Johansen procedure and the Granger causality Wald test.

Significant linkages were reported for long-term interrelationships between the analyzed indices. In the first investigated period we revealed eleven, and in the second period six cases of cointegration. This was indicative of long-term interrelationships between selected indices and of some changes in these interrelationships before and after the crisis. Long-term interrelationships were observed primarily between the stock indices in the developed countries, but the number of observed relations was significantly reduced in the second period. Before the crisis all the indices in the developed countries were cointegrated, while in the second period only three significant interrelations were observed. The changes also concerned interrelations between the stock market indices in Central Europe; before the crisis two cointegrations were observed and none in the second period. The changes also involved interrelationships between the stock market indices in Western Europe and in Central Europe. We revealed three cointegrations in each of the two periods but the relationships in each period concerned different indices which allowed us to confirm the first and the third hypotheses about the long-term interrelationships between some stock indices and their evolution over time.

The findings from our investigation confirmed Granger causality between the stock indices included in the study. Before the crisis, seven bidirectional and nine unidirectional relationships were reported. Bidirectional causality relationships were 
observed between all indices in the developed countries with the exception of one pair of indices: the CAC and the FTS, where unidirectional relationship was detected. In the case of stock exchanges in Central Europe, causal relationships were restricted; there were only two unidirectional relationships. Causal relationships were revealed also between the BUX and the WIG indices and indices in advanced economies. In this case unidirectional relationships dominated and changes in the stock markets in Budapest and in Warsaw were triggered by changes in the stock exchanges in Western Europe and in the United States. In the second research period there were eleven bidirectional and seven unidirectional relationships. In comparison with the period before the crisis, the deepest changes took place in the stock exchanges in Central Europe. Bidirectional relationships were observed between all the indices in the region while earlier only two unidirectional relationships were reported. In the case of stock exchanges in advanced economies, there was causal relationship between the majority of the investigated indices confirming relationships, which turned out to be stable, regardless of the period. Clear changes took place in causal relationships between the stock indices in the advanced economies and in Central Europe. In some cases the directions of earlier observed relationships changed and only for the BUX index we could maintain the view that stock exchanges in developed countries influenced changes in the performance of the Hungarian stock exchange. The results of the analysis helped us adopt hypothesis $\mathrm{H} 2$ about causal relationships between some indices included in the study. When it comes to hypothesis $\mathrm{H} 3$ about changes in causal relationships we may say that most of these relations were unstable in time, but we must stress that some indices from the developed countries maintained the same bidirectional causality relationships in both periods of the study.

This analysis belongs to research on the relationships between stock indices and investigates the effect of the 2008 financial crisis for relationships observed between selected indices from Western Europe, Central Europe and the United States. The results show that relationships between the stock indices in the developed countries were more numerous and durable than between the stock indices in Central Europe but they were subject to some fluctuations. The relationships between the indices from the developed countries and from Central Europe also fluctuated. Instability over time was most clear for long-term interrelationships; out of the eleven cointegrations in the first research period only three survived and remained unchanged. Instability in long-term relationships may be the effect of the 2008 financial crisis. The changing course of the crisis in individual countries and differences in monetary policies resulted in the diverse performance of individual stock markets [Laeven, Tong 2012]. In the analysis of causal relationships in the Granger sense we also observed changes in relationships and their directions. However, we need to stress the presence of bidirectional relationships between indices in the developed economies that are stable over time. Major changes in causal relationships also emerged in Central European markets after 2008. New 
bidirectional relationships were observed between the emerging markets covered by the study, which is indicative of their advancing integration within the EU. The amount of causal relationships with developed markets also increased which should be seen as evidence of the strengthening links between the markets of Central Europe and the developed countries. The obtained results revealed new dependences because earlier studies did not report changes in links amongst markets in Central Europe [Demian 2011].

\section{Bibliography}

Augustyński I., 2011, Wpływ giełd światowych na główne indeksy giełdowe w Polsce, Finansowy Kwartalnik Internetowy „e-Finanse”, vol. 7, no. 1, pp. 1-12.

Avdulaj K., Barunik J., 2013, Can we still benefit from international diversification? The case of the Czech and German stock markets, Czech Journal of Economics and Finance, vol. 63, no. 5, pp. 425-442.

Baumohl E., Vyrost T., 2010, Stock market integration: Granger causality testing with respect to nonsynchronous trading effects, Czech Journal of Economics and Finance, vol. 60, no. 5, pp. 414-425.

Chow G.C., 1960, Tests of equality between subsets of coefficients in two linear regression models, Econometrica, vol. 28, no. 3, pp. 591-605.

Cukierman A., 2013, Monetary policy and institutions before, during, and after the global financial crisis, Journal of Financial Stability, vol. 9, no. 3, pp. 373-384.

Czapkiewicz A., Jamer P., 2015, Dynamika wspótzależności warszawskiej Giełdy Papierów Wartościowych z innymi rynkami finansowymi, Ekonometria, vol. 2, no. 48, pp. 100-113.

Demian C.V., 2011, Cointegration in Central and East European markets in light of EU accession, Journal of International Financial Markets, Institutions \& Money, vol. 21, no. 1, pp. 144-155.

Dickey D.A., Fuller W.A., 1979, Distribution of the estimators for autoregressive time-series with a unit root, Journal of the American Statistical Association, vol. 74, no. 366, pp. 427-431.

Doman M., Doman R., 2013, The Dynamics and strength of linkages between the stock markets in the Czech Republic, Hungary and Poland after their EU Accession, Dynamic Econometric Models, vol. 13, pp. 5-31.

Engle R.F. Granger C.W.J., 1987, Co-integration and error correction: representation, estimation and testing, Econometrica, vol. 55, no. 2, pp. 251-276.

Evrim-Mandaci P., Cagli E.C., 2012, Relationships between the US and European stock markets during the recent financial turmoil: Evidence from the VARFIMA model, Applied Economics Letters, vol. 19, no. 17, pp. 1697-1701.

Gjika D., Horvath R., 2013, Stock market co-movements in Central Europe: Evidence from the asymmetric DCC model, Economic Modelling, vol. 33, pp. 55-64.

GPW, 2017, Udziat inwestorów w obrotach giełdowych - dane zagregowane 1996-2016, https://www. gpw.pl (11.12.2017).

Granger C.W.J., 1969, Investigating causal relations by econometric models and cross-spectral methods, Econometrica, vol. 37, no. 3, pp. 424-438.

Hilliard, J.E., 1979, The relationship between equity indices on world exchanges, Journal of Finance, vol. 34, no. 1, pp. 103-114.

Hołubowicz K., 2014, Korelacja indeksów cen akcji na globalnych rynkach finansowych, Nauki o Finansach, vol. 2, no. 19, pp. 71-81, 
Johansen S., 1988, Statistical analysis of cointegration vectors, Journal of Economic Dynamics and Control, vol. 12, no. 2-3, pp. 231-254.

Kwan A.C.C., Sim A.B., Cotsomitis J.A., 1995, The causal relationships between equity indices on world exchanges, Applied Economics, vol. 27, no. 1, pp. 33-37.

Kwiatkowski D., Phillips P.C.B., Schmidt P., Shin Y., 1992, Testing the null hypothesis of stationarity against the alternative of a unit root: how sure are we that economic time series have a unit root?, Journal of Econometrics, vol. 54, no. 1-3, pp. 159-178.

Laeven L., Tong H., 2012, US monetary shocks and global stock prices, Journal of Financial Intermediation, vol. 21, no. 3, pp. 530-547.

Lothian J.R., 2002, Internationalization of money and the globalization of financial markets, Journal of International Money and Finance, vol. 21, no. 6, pp. 699-724.

Malliaris A.G., Urrita J., 1992, The international crash of October 1987: Causality tests, Journal of Financial and Quantitative Analysis, vol. 27, no. 3, pp. 353-364.

Masih A.M.M., Masih R., 2001, Long and short term dynamic causal transmission amongst international stock markets, Journal of International Money and Finance, vol. 20, no. 4, pp. 563-587.

Masih A.M.M., Masih R., 2002, Propagative causal price transmission among international stock markets: Evidence from the pre and post-globalization period, Global Finance Journal, vol. 13, no. 1, pp. 63-91.

Ozdemir Z.A., Olgun H., Saracoglu B., 2009, Dynamic linkages between the center and periphery in international stock markets, Research in International Business and Finance, vol. 23, no. 1, pp. 46-53.

Prenzena P., 2016, Analiza powiąań między indeksami gietdy francuskiej, holenderskiej i belgijskiej z wykorzystaniem modelu korekty błędem, Studia Ekonomiczne Zeszyty Naukowe Uniwersytetu Ekonomicznego w Katowicach, vol. 289/16, pp. 109-126.

Smith K.L., Brocato J., Rogers J.E., 1993, Regularities in the data between major markets: Evidence from Granger causality tests, Applied Economics, vol. 3, no. 1, pp. 55-60.

Syllignakis M.N., Kouretas G.P., 2011, Dynamic correlation analysis of financial contagion: Evidence from the Central and Eastern European markets, International Review of Economics and Finance, vol. 20 , no. 4 , pp. 717-732.

Syriopoulos T., 2004, International portfolio diversification to Central European stock markets, Applied Financial Economics, vol. 14, no. 17, pp. 1253-1268.

Tavares J., 2009, Economic integration and the co-movement of stock returns, Economics Letters, vol. 103, no. 2, pp. 65-67.

Tintin C., 2013, The determinants of foreign direct investment inflows in the Central and Eastern European Countries: The importance of institutions, Communist and Post-Communist Studies, vol. 46, no. 2, pp. 287-298.

Yang L., Tapon F., Sun Y., 2006, International correlations across stock markets and industries: Trends and patterns 1988-2002, Applied Financial Economics, vol. 16, no. 16, pp. 1171-1183.

\section{ANALIZA PRZYCZYNOWOŚCI MIĘDZY GIELDOWYMI INDEKSAMI AKCJI}

Streszczenie: Artykuł analizuje współzależności między wybranymi indeksami giełd z Europy Zachodniej, Europy Środkowej i Stanów Zjednoczonych. Badane są dwa okresy: od stycznia 1998 r. do sierpnia 2006 r. i od września 2006 r. do grudnia 2016 r. Pierwszy obejmuje notowania giełdowe przed kryzysem finansowym, natomiast drugi uwzględnia kryzys i zmiany koniunktury w latach pokryzysowych. Zależności między indeksami w państwach rozwiniętych były liczniejsze i trwalsze niż między in- 
deksami giełd z Europy Środkowej, ale podlegały zmianom. W analizie relacji przyczynowych w sensie Grangera obserwowano zmiany zależności i ich kierunków w przypadku giełd z Europy Środkowej, natomiast stabilne w czasie relacje dwukierunkowe występowały między indeksami państw rozwiniętych. Zmiany w relacjach między indeksami, zwłaszcza współzależności długoterminowych, mogą wynikać z wpływu kryzysu finansowego w roku 2008. Wzrost liczby relacji przyczynowych dla rynków z Europy Środkowej może świadczyć o postępującej integracji wspólnego rynku Unii Europejskiej.

Słowa kluczowe: rynek akcji, kointegracja, przyczynowość w sensie Grangera, kryzys finansowy. 